\title{
Hyperreality and Simulacrum: Jean Baudrillard and European Postmodernism
}

\author{
Ryszard W. Wolny \\ Institute of English and American Studies \\ University of Opole, Poland
}

\begin{abstract}
The aim of this paper is to present and explore one of the most fundamental concepts of postmodernity, that is, Jean Baudrillard's elaboration of the ideas of hyperreality and simulacrum that characterise today's global consumer culture in which the image of the product is more significant that the product itself. Some attention has also been devoted to European postmodernism, Jean-François Lyotard's concept of the postmodern articulated in his renown book, The Postmodern Condition, in particular, and the merging of high and popular cultures to form consumer culture of late capitalism.
\end{abstract}

Keywords: Jean Baudrillard, hyperreality, simulacrum, postmodernity, consumer society

\section{Introduction}

The contemporary world cannot be properly understood without the knowledge of the profound intellectual changes that occurred in the 1960s in Europe and particularly in France.

Broadly speaking, the $20^{\text {th }}$ century witnessed the rise of structuralism and, in its second half - its corrected form, poststructuralism, alongside the emergence of what we now term postmodernity and the postmodern. There is, however, no universal agreement as to what the latter terms really denote; nonetheless, for the purpose of this paper, I shall concentrate on just a few characteristic features that may prove significant for the further discussion, one of which is the power of the image and simulacrum within consumer culture that dominated the post-industrial era. Even though most of the attention has been paid to Jean-François Lyotard's celebrated statement of postmodernity's suspicion of grand narratives, I agree with Wolfreys et al (2006) in saying that

[t]he idea of a postmodern era is also provisionally defined by the advent of tele-technologies, the emergence of globalisation and post-industrial society, and the power of the image and simulacrum within consumer culture, where images such as the Coke or Nike logos assume greater significance in themselves than any real product or reality to which they might refer. (80, bold in original)

Therefore, what we witness today is, fundamentally, the rejection and erasure of the original to the advantage of the copy, the image, the visual. The advent of the tele-technologies and their ascendancy over the minds of billions of consumers across the globe makes human life multidimensional not just in terms of conventional 3D technologies but in terms of other realities - hyperrealities - such as virtual reality or extended/augmented reality; hence a need to re-define the ideas of human life and its reality.

\section{Jean Baudrillard}

Jean Baudrillard's published work emerged as part of a generation of French thinkers including Jean-François Lyotard, Gilles Deleuze, Michael Foucault, Jacques Derrida and Jacques Lacan who all shared an interest in semiotics, and he is often seen as a part of the poststructuralist philosophical school. In common with many post-structuralists, his arguments consistently draw upon the notion that signification and meaning are both only understandable in terms of how particular words or signs interrelate. Baudrillard thought, as do many post-structuralists, that meaning is brought about through systems of signs working together. Following on from Ferdinand de Saussure, Baudrillard argued that meaning (value) is created through difference-through what something is not. In fact, he viewed meaning as near enough self- 
referential: objects, images of objects, words and signs are situated in a web of meaning; one object's meaning is only understandable through its relation to the meaning of other objects.

From this starting point Baudrillard theorised broadly about human society based upon this kind of self-referentiality. His writing portrays societies always searching for a sense of meaning - or a total understanding of the world-that remains consistently elusive. In contrast to poststructuralism and Michel Foucault, for whom the formations of knowledge emerge only as the result of relations of power, Baudrillard developed theories in which the excessive, fruitless search for total knowledge leads almost inevitably to a kind of delusion. In Baudrillard's view, the (human) subject may try to understand the (non-human) object, but because the object can only be understood according to what it signifies (and because the process of signification immediately involves a web of other signs from which it is distinguished) this never produces the desired results. The subject is, rather, seduced (in the original Latin sense, seducere, to lead away) by the object. He argued therefore that, in final analysis, a complete understanding of the minutiae of human life is impossible, and when people are seduced into thinking otherwise they become drawn toward a "simulated" version of reality, or, to use one of his neologisms, a state of hyperreality. (wikipaedia)

\section{Hyperreality vs Reality}

In hyperreality, the "original" version of an object has no real significance since it belongs to a different realm and therefore loses its referential value. This is not to say that the world becomes unreal, but rather that the faster and more comprehensively societies begin to bring reality together into one supposedly coherent picture, the more insecure and unstable it looks and the more fearful societies become. Reality, in this sense, dies out. As Baudrillard defined it, hyperreality is "the meticulous reduplication of the real, preferably through another, reproductive medium, such as photography" (in Wolfreys et al 52), and that is what happens in contemporary consumer culture: the picture of a product also a rock star or a film celebrity - is more important than the original since the context - the environment - adds to the value of the "original" product either in the form of "photo shop," clearing off all imperfections of the face, or through extensive (and expensive) product placement campaigns, advertisements, billboards, public relations programmes, etc.

Baudrillard argued that the excess of signs and of meaning in late 20th century global society had caused, quite paradoxically, an effacement of reality. In this world neither liberal nor Marxist utopias are any longer believed in. We live, he argued, not in a global village, to use Marshall McLuhan's phrase, but rather in a world that is ever more easily petrified by even the smallest event. Because the global world operates at the level of the exchange of signs and commodities, it becomes ever more blind to symbolic acts such as, for example, terrorism. In Baudrillard's work the symbolic realm (which he develops a perspective on through the anthropological work of Marcel Mauss and Georges Bataille) is seen as quite distinct from that of signs and signification. Signs can be exchanged like commodities; symbols, on the other hand, operate quite differently: they are exchanged, like gifts, sometimes violently as a form of potlatch ${ }^{1}$. Baudrillard, particularly in his later work, saw the global society as without this symbolic element, and therefore symbolically (if not militarily) defenceless against acts such as the Rushdie Fatwa or, indeed, the 9/11 attacks against the United States and its military and economic establishment. In his provocative book of 1991, The Gulf War Did Not Take Place, Baudrillard attempted to demonstrate that contemporary wars are being fought as much on the battlefields as on television, and thus one cannot dissolve the physical reality from its media representation, particularly in the context of military operations and their political and ideological motivations. He writes:

Non-war is a terrible test of the status and the uncertainty of politics, just as a stock market crash (the speculative universe) is a crucial test of the economy and of the uncertainty of economic aims, just as any event whatever is a terrible test of the uncertainty and the aims of information. Thus "real time" information loses itself in a completely unreal space, finally furnishing the images of pure, useless, instantaneous television where its primordial function irrupts, namely that of filling a vacuum, blocking up the screen hole through which escapes the substance of events. (30-31)

\footnotetext{
1 In his book, The Gift, the French ethnologist, Marcel Mauss used the term potlatch to refer to a whole set of exchange practices in tribal societies characterized by "total prestations," i.e., a system of gift giving with political, religious, kinship and economic implications.

These societies' economies are marked by the competitive exchange of gifts, in which gift-givers seek to out-give their competitors so as to capture important political, kinship and religious roles.
} 
This severe criticism of hyperreality created by television and of information provided in "real time," in particular, was supposed to be, undoubtedly, Baudrillard's political and cultural declaration that, in fact, it is the media - not the governments - that have most power in the western world:

The media promote the war, the war promotes the media, and advertising competes with the war. Promotion is the most thick-skinned parasite in our culture. It would undoubtedly survive a nuclear conflict. It is our Last Judgement. But it is also like biological function: it devours our substance, but it also allows us to metabolise what we absorb, like a parasitic or intestinal flora, it allows us to turn the world and the violence of the world into a consumable substance. So, war or promotion? (31)

This attack on the media that promote the war by broadcasting it only proves their complete control over the "real time" and the "real reality," thus arguing for these specifically late $20^{\text {th }}$-century phenomena of hyperreality and the image of what once was called reality, i.e., simulacrum.

\section{Simulacrum}

Simulacrum (simulacra, in plural) is the term closely associated with the work of Jean Baudrillard and which, roughly, denotes likeness or/and similarity. At first, around the $16^{\text {th }}$ century when it entered the English language, it was used to stand for a representation of a superior kind such a statue of a divinity and, then, around the close of the $19^{\text {th }}$ century, its meaning considerably deteriorated to become synonymous with an inferior image lacking the quality of the original. In Key Concepts in Literary Theory (2006), Wolfreys et al argue that the term is bound up in Baudrillard's "reality effect," that

relates to the ways in which reality is often established and becomes replaced for some individuals and cultures through hyperreal media such as photography, film and other media; hence, simulacrum refers to the image, representation or reproduction of a concrete other in which the very idea of the real is no longer the signified of which the simulacrum is the signified. (92)

They also speak of the process connected with simulacrum and simulacra, that is, simulation:

Simulation, the process whereby simulacra assume their function, belongs to what Baudrillard terms the 'second order': there is no anterior 'real' only coming into being through the cultural dissemination of images (such as those of advertising) or simulacra. (92)

Simulation is, thus, the process of de-realisation of reality into simulacra, or inferior representations, which, on the other hand, signifies postmodern tendency to seriously question the idea of a beginning and origin. This clearly anti-Platonic stance stands in a stark contrast to what Plato and his followers believed, i.e. the superiority of an idea over reality, which is then copied or imitated by artists. Platonism has set the centuries-long European tradition of hierarchical opposition between nature and civilisation and the real and its image. But what when there is no real at all? In "Simulacra and Simulation," Baudrillard gives an answer:

When the real is no longer what it used to be, nostalgia assumes its full meaning. There is a proliferation of myths of origin and signs of reality; of second-hand truth, objectivity and authenticity. There is an escalation of the true, of the lived experience; a resurrection of the figurative where the object and substance have disappeared. And there is a panic-stricken production of the real and the referential. This is how simulation appears in the phase that concerns us: a strategy of the real, neo-real and hyperreal, whose universal double is a strategy of deterrence. (Selected Writings 166-184)

Like in Derrida's deconstructivist strategy, meaning is deterred, endlessly postponed, suspended and undecided.

\section{On Unrepresentabilty of Divinity}

Baudrillard also discussed the idea of God's representation as the most traditional area of simulation and, at the same time, the most dangerous one since if God had been represented in pictures, portraits, paintings, i.e. as a simulacrum, it meant that he had never existed as real in real time and space:

Outside of medicine and the army, favored terrains of simulation, the affair goes back to religion and the simulacrum of divinity: "I forbade any simulacrum in the temples because the divinity that breathes life into nature cannot be represented." Indeed it can. But what becomes of the divinity when it reveals itself in icons, when it is multiplied in simulacra? Does it remain the supreme authority, simply incarnated in images as a visible theology? Or is it volatilized into simulacra which 
alone deploy their pomp and power of fascination-the visible machinery of icons being substituted for the pure and intelligible Idea of God? This is precisely what was feared by the Iconoclasts, whose millennial quarrel is still with us today. Their rage to destroy images rose precisely because they sensed this omnipotence of simulacra, this facility they have of erasing God from the consciousnesses of people, and the overwhelming, destructive truth which they suggest: that ultimately there has never been any God; that only simulacra exist; indeed that God himself has only ever been his own simulacrum. Had they been able to believe that images only occulted or masked the Platonic idea of God, there would have been no reason to destroy them. One can live with the idea of a distorted truth. But their metaphysical despair came from the idea that the images concealed nothing at all, and that in fact they were not images, such as the original model would have made them, but actually perfect simulacra forever radiant with their own fascination. But this death of the divine referential has to be exorcised at all cost. (169, emphasis added)

In this sense, we may argue after Baudrillard, religion becomes the most primitive, primordial form of simulation, and divinities have been the oldest form of simulacra. Interestingly enough, in Baudrillard's view, iconolaters have to be considered as possessing the most modern (today we would say - postmodern) minds since,

underneath the idea of the apparition of God in the mirror of images, they already enacted his death and his disappearance in the epiphany of his representations (which they perhaps knew no longer represented anything, and that they were purely a game, but that this was precisely the greatest game-knowing also that it is dangerous to unmask images, since they dissimulate the fact that there is nothing behind them). (170)

Yet, as Baudrillard argues, the power has remained with the images as the "murderers" of the real, "murderers of their own model as the Byzantine icons could murder the divine identity" (170), emphasising the significance of representation that a sign referred directly to its underlying concept (meaning) and that God, for instance, was supposed to guarantee this exchange:

But what if God himself can be simulated, that is to say, reduced to the signs which attest his existence? Then the whole system becomes weightless; it is no longer anything but a gigantic simulacrum: not unreal, but a simulacrum, never again exchanging for what is real, but exchanging in itself, in an uninterrupted circuit without reference or circumference. (171)

This self-propelled machine of signification's self-exchange does not refer to anything beyond itself (Derrida will argue later that there is no outside of the text); hence this assertion that the whole of signification is "an uninterrupted circuit without reference or circumference." And that sound very much postmodern.

\section{The Postmodern}

It is, indeed, a daunting task to define the postmodern and postmodernism since, by its very nature, the postmodern evades any conclusive statements and canonical truths about itself, thus any definition of the postmodern would be very much a denial of itself and, in fact, anti-postmodern. Nevertheless, for the purpose of this brief paper, I shall try to find some common premises from which the postmodern stems and group them in more or less coherent whole as fragments of the great unknown and the unknowable.

The starting remark will be ideological. In the prevailing view of the artists and critics working in the late 1950s and the early 1960s, such as Susan Sontag and Leslie Fiedler, modernism was too canonical and, to a great extent, represented the bourgeois culture of the modern capitalist world. The power of the modernist icons, James Joyce, T.S. Eliot, Virginia Woolf, D.H. Lawrence, for instance, instead of shocking and disturbing the petrified social hierarchy and middle-class values, made them classical, canonical and high culture (which they in fact still are today!). For the young generation of the 1960s, the post-war generation of baby-boomers, the dead classics became a burden too heavy to bear, particularly in the face of the decline of the university and the shift towards the mass and consumer culture. The result was a new phase of Marxist commodity fetishism, a fascination for images and the visual, the implosion of meaning, fragmentation of the self, decentering of the subject and the collapse of the cultural hierarchies.

Another point of significance is the moment when the post-moderns decided to abolish, or at least to blur, the difference between the high, elitist culture of modernism and the low, popular one of the current times. As Storey (1999) has it,

[t]he postmodernism of the 1960s was therefore in part a populist attack on the elitism of modernism. It signalled a refusal of what Andreas Huyssen calls 'the great divide ... [a] discourse which insists on the categorical; distinction between high art and mass culture'. Moreover, according to Huyssen, 'To a large extent, it is by the distance we have travelled from this 
"great divide" between mass culture and modernism that we can measure our own cultural postmodernity.' In spite of this, or perhaps because of it, [...] , postmodernism signifies a culture of kitsch, when measured against the supposedly 'real' culture of modernism. (148)

This "real" culture of modernism has, in the process of incessant simulation, been re-duplicated to become "non-real," comic, imaginary. Andy Warhol, the icon of American pop art, saw commercial art as real art and real art as commercial one since he believed that art had always been in the possession of the ruling class and in the post-war America, as opposed to Britain and the rest of Europe, the ruling class was different and as was its taste and wealth. The practical example of the merging of "high" and "low" cultures was the fact that the artist, Andy Warhol, designed the Rolling Stones' album Sticky Fingers and another artist, Peter Blake - the Beatles' Sergeant Pepper's Lonely Hearts Club Band album, thus proving that pop music and pop art have the identical artistic and commercial aims.

Finally, the theorist who introduced the term "postmodernism" into circulation was the Frenchman, Jean-François Lyotard, whose book, The Postmodern Condition, published in France in 1979 and then translated into English in 1984, has been considered to found the principles of the movement. For Lyotard, the postmodern condition was marked with the crisis of the status of knowledge expressed as incredulity towards metanarratives (also called grand narratives) like Christianity, liberalism (and later, neo-liberalism), Marxism, etc., with their privileged truths to tell. Instead, what becomes more and more audible are the so far stifled voices from the margin, advocating for difference, diversity and heterogeneity. In a similar way, Lyotard is sceptical of and suspicious to science that, in an aftermath of the Enlightenment, offers the best and the only path to the emancipation of humanity, thus assuming itself the status of a metanarrative. So does the higher education, which is the product of capitalism and the subject to market economy and is judged on the basis of its performativity (like science) and not by the ideals it is supposed to instil in students. Knowledge and universities are no longer seen as an end in themselves but as a means to an end. And, as Lyotard concludes on a brighter note, postmodernism breaks with one modernism to form a new modernism, arguing that a work can become modern only if it is first postmodern.

\section{References}

[1] Baudrillard, Jean. Simulacra and Simulation. Selected Writings. Ed. Mark Poster. Stanford: Stanford University Press, 1988: 166-184. Print.

[2] Baudrillard, Jean. The Gulf War Did Not Take Place. Trans. and Intr. Paul Patton. Bloomington and Indianapolis: Indiana University Press, 1991. Print.

[3] Bennett, Andrew and Nicholas Royle. Introduction to Literature, Criticism and Theory. $2^{\text {nd }}$ Edition. London and New York: Prentice Hall, 1999. Print.

[4] Jean Baudrillard. Wikipaedia. En. Wikipaedia.org. web. 16 Apr 2017. Web.

[5] Lyotard, Jean-François. The Postmodern Condition: A Report on Knowledge. Trans. Geoffrey Bennington and Brian Massumi. Minneapolis: University of Minnesota Press, 1984 [La Condition postmoderne: Rapport sur le savoir. Paris: Éditions de Minuit, 1979]. Print.

[6] Storey, John. Cultural Theory and Popular Culture. An Introduction. London and New York: Routledge, 1999. Print.

[7] Wolfreys, Julian, Ruth Robbins and Kenneth Womack. Key Concepts in Literary Theory. ${ }^{\text {nd }}$ Edition. Edinburgh: Edinburgh University Press, 2006. Print. 